\title{
Effect of Seedling Dip and Pre Harvest Foliar Application of Growth Regulators and Fungicide on Sprouting and Chemical Parameters in Onion (Allium cepa L.) var. Arka Kalyan
}

\author{
Ayeeshya Hasansab Kolhar*, S.L. Jagadeesh and Vijaymahantesh \\ College of Horticulture, Bagalkot, University of Horticultural Sciences, \\ Bagalkot-587104, Karnataka, India \\ *Corresponding author
}

\begin{abstract}
Keywords
Onion, Salicylic acid, Azoxystrobin and Cycocel

Article Info

Accepted:

10 March 2019

Available Online:

10 April 2019 Randomized Complete Block Design, with 12 treatments and 3 replication. The harvested bulbs were kept in storage for 4 months at ambient condition during which various physical parameters including sprouting and chemical parameters like pyruvic acid and total soluble solids were analysed. The reduction in the mean sprouting i.e., 2.26 per cent was observed in bulbs with salicylic acid at $2 \mathrm{mM}$ (seedling dip and foliar spray $60+90$ DAT), azoxystrobin at $0.1 \%$ (foliar spray at $60+90$ DAT) and cycocel at $2500 \mathrm{ppm}$ (foliar spray at 90 DAT), bulbs treated with salicylic acid at $2 \mathrm{mM}$ (seedling dip and foliar spray $60+90$ DAT), azoxystrobin at $0.1 \%$ (foliar spray at $60+90$ DAT) exhibited maximum mean pyruvic acid content $8.71 \mu$ moles/g during prolonged storage of 120 days. The bulbs treated with salicylic acid $2 \mathrm{mM}(60+90$ DAT), azoxystrobin $0.1 \%(60+90 \mathrm{DAT})$ and cycocel $2500 \mathrm{ppm}$ (90 DAT) exhibited maximum total soluble solids. Thus in the present investigation the combined application of salicylic acid, azoxystrobin and cycocel in field reduced sprouting, increased pyruvic acid and total soluble solids in onion cv. Arka kalyan during prolonged storage period.
\end{abstract}

A B S T R A C T

A field study was conducted to know the effect of field application of salicylic acid, azoxystrobin and cycocel on storage behavior of onion cv. Arka Kalyan during kharif season of 2016-17 at College of Horticulture, Bagalkot. The experiment was laid out in

\section{Introduction}

Onion (Allium cepa L.) is one of the most important bulb crops of India. India is the $2^{\text {nd }}$ largest producer of onion in the world next only to China, occupying an area of around 1.67 lakh ha with production of 202.14 lakhs MT and productivity of $17.32 \mathrm{t} / \mathrm{ha}$. Out of which, around 65 per cent produce which comes from rabi season is partly used for domestic consumption as well as storage for further consumption in different parts of the country from June to November along with the fresh produce of early kharif and late kharif onion. As per the NHRDF's estimate, around 45-46 lakh MT onions have been stored in the year 2016-17 by farmers as well as traders which is around 15 per cent more 
compared to 2015-16. Around 12-15 lakh MT onions are required per month for consumption in our country (Anon., 2016). The stored bulbs need to meet consumer demand during off-season with good quality. On the other hand, several factors such as respiration, sprouting and rotting accounts for about 50-90 per cent storage losses depending upon genotype and storage conditions (Shivakumar and Chandrashekar, 2014).

The pre harvest application of the fungicide and growth regulator is well known to enhance the post harvest shelf life and quality of onion bulbs during storage. Based on this hypothesis, the present investigation aims at reducing the post harvest losses and retains the quality of stored onion bulbs. Application of these chemicals is known to be beneficial to reduce the post harvest loss of onion bulbs in storage by inhibition of sprouting, rotting and reduction in the physiological loss in weight when applied as pre-harvest sprays and as a seedling dip. Keeping all these points in view, the present study was carried out with an intention of determining the effect of seedling dip and pre-harvest foliar spray of salicylic acid, azoxystrobin and cycocel on storage behavior, particularly sprouting of onions and further to study the biochemical quality of stored onions at regular intervals as influenced by different treatments.

\section{Materials and Methods}

The investigation was carried out at College of Horticulture, Bagalkot, Karnataka during Kharif season of 2016-17. Onion cv. Arka Kalyan was subjected to 12 treatments in RCBD with three replications. The seedlings of cv. Arka Kalyan were raised on raised bed of size $4.0 \mathrm{~m} \times 1.0 \mathrm{~m}$ are transplanted to the main field of size $1.8 \mathrm{~m} \times 1.8 \mathrm{~m}$ with a spacing of $15 \mathrm{~cm} \times 10 \mathrm{~cm}$. Twelve different treatments comprising of SA @ $2 \mathrm{mM}$, as a seedling dip and foliar spray at 60+90 DAT, azoxystrobin $(0.1 \%)$ at $60+90$ DAT and the growth retardant cycocel @ 2500 ppm at 90 DAT were applied as alone and in combination with each other. These treatments are $\mathrm{T}_{1}$ as control, SA $2 \mathrm{mM} @ 60$ + 90 DAT $\left(\mathrm{T}_{2}\right)$, SA $2 \mathrm{mM}$ as seedling dip and at $60+90$ DAT $\left(\mathrm{T}_{3}\right),\left(\mathrm{T}_{4}\right)$ azoxystrobin $(0.1 \%)$ at $60+90 \mathrm{DAT},\left(\mathrm{T}_{5}\right) \mathrm{SA} 2 \mathrm{mM}+$ azoxystrobin $0.1 \%$ at $60+90$ DAT, SA @ 2 $\mathrm{mM}$ as seedling dip and SA $2 \mathrm{mM}$ and azoxystrobin $(0.1 \%)$ at $60+90$ DAT $\left(\mathrm{T}_{6}\right)$, cycocel $2500 \mathrm{ppm}$ at $90 \mathrm{DAT}\left(\mathrm{T}_{7}\right)$, SA $2 \mathrm{mM}$ at $60+90 \mathrm{DAT}$ and cycocel $2500 \mathrm{ppm}$ at 90 DAT $\left(\mathrm{T}_{8}\right)$, SA @ $2 \mathrm{mM}$ as seedling dip and at $60+90$ DAT and cycocel $2500 \mathrm{ppm}$ at 90 DAT $\left(\mathrm{T}_{9}\right)$, azoxystrobin $(0.1 \%)$ at $60+90$ DAT cycocel $2500 \mathrm{ppm}$ at 90 DAT $\left(\mathrm{T}_{10}\right)$, ( $\left.\mathrm{T}_{11}\right) \mathrm{SA} @ 2 \mathrm{mM}$ and azoxystrobin @ 0.1\% at $60+90$ DAT and cycocel @ 2500 ppm at 90 DAT) and $\left(\mathrm{T}_{12}\right)$ seedling dip in SA @ 2 $\mathrm{mM}$ followed by SA @ 2mM and azoxystrobin@0.1\% at $60+90$ DAT and cycocel 2500 ppm @ 90 DAT.

The bulbs were harvested at 120 DAT after attaining the maturity i.e., at 50 per cent neck fall and are well cured and packed in jute mesh gunny bag of size $45 \mathrm{~cm} \times 60 \mathrm{~cm}$ and subjected to storage studies in ambient condition for 4 months. During storage physical parameter like sprouting per cent and bio chemical parameter such as pyruvic acid, total soluble solids were estimated initially and at monthly intervals.

\section{Sprouting per cent}

The sprouting per cent is determined following the procedure adopted by Kukanoor, L., 2005 (10), during prolong storage of 4 months storage at monthly interval. The sprouted bulbs were separated from the lot and weighed on an electronic balance and sprouting per cent, at 30,60,90 and 120 DAS, was calculated by using the formula. 
Sprouting per cent $=$

$\frac{\text { Weight of the sprouted bulbs (E) }}{\text { Initial weight of bulbs (g) }} \times 100$

The chemical parameters pyruvic acid $(\mu \mathrm{mol} / \mathrm{g})$ was estimated as per the procedure followed by Ketter and Randle (1998) and total soluble solids $\left(\mathrm{TSS}^{\circ} \mathrm{B}\right)$ determined by using ERMA hand refractometer.

\section{Results and Discussion}

\section{Sprouting}

Sprouting is the major factor limiting the storability of onion bulbs (Chope et al., 2006) 7. The effect of field application of SA, azoxystrobin and cycocel on sprouting of onion during prolonged storage of 4 months is presented in the Table 1 . The bulbs harvested by dipping the seedlings in SA @ $2 \mathrm{mM}$ followed by foliar spray of SA @ $2 \mathrm{mM}$, azoxystrobin@0.1\% and CCC 2500 ppm at 90 DAT $\left(\mathrm{T}_{12}\right)$ exhibited least per cent sprouting $(2.26 \%)$ which was followed by bulbs treated with SA @ $2 \mathrm{mM}$ and azoxystrobin@ $0.1 \%$ at $60+90$ DAT and cycocel @ 2500 ppm at 90 DAT $\left(\mathrm{T}_{11}\right)$ $(2.82 \%)$ which may be due to the combined application of chemicals might have an effect in sprout suppression. This indicates the existence of synergy among the chemicals and each chemical might have been contributed for sprout suppression. The fungicide azoxystrobin is known to influence physiology of the plant, causes hormonal balance, favouring cytokinin as opposed to ethylene and causing up to a two fold increase in endogenous level of abscisic acid (ABA) a hormone which checks the growth. The phytohormone ABA plays an important role in many physiological processes in plants. This hormone is necessary for regulation of several events during late seed development and is crucial for the response to environmental stresses (Anatonio et al.,
2012). The salicylic acid treated plants accumulated high concentration of ABA (Sakhabutdinova et al., 2003) which is a growth inhibitor. The growth regulator cycocel is known to prolong the dormancy for longer period after harvest and is attributed to reduced neck thickness in sprayed bulbs and by way of minimized cell division and due to the removal of apical dominance inhibiting sprout initiation. The results of the present investigation are in conformity with the findings of Anbukkarasai et al., (2013).

\section{Total soluble solids (TSS)}

In the present investigation field application of SA, azoxystrobin and cycocel was known to significantly influence the TSS of the stored onion bulbs which clear from the Table 2. The bulbs imposed with SA @ $2 \mathrm{mM}$ and azoxystrobin @ $0.1 \%$ at $60+90$ DAT followed by CCC 2500 ppm at 90 DAT $\left(15.14^{\circ} \mathrm{B}\right) \quad\left(\mathrm{T}_{11}\right)$ exhibited maximum TSS. Which is followed by treatment $\mathrm{T}_{12}$ (seedling dip in salicylic acid @ $2 \mathrm{mM}+$ Pre-harvest spray of salicylic acid @ 2 mM and azoxystrobin @ $0.1 \%$ at $60+90$ DAT followed by CCC $2500 \mathrm{ppm}$ foliar spray 90 DAT) $\left(14.93^{\circ} \mathrm{B}\right)$. It may be due to high dry matter bulbs (results are not shown) are able to accumulate higher TSS concentrations without taking up more water because of their ability to synthesize and store highly polymerized fructans.

The highest TSS content in onion bulbs was mainly attributed to the maximum conversion of polysaccharides into soluble forms of sugars. The foliar sprays of these chemicals was effective in increasing the TSS content of onion which might be due to faster conversion of insoluble sugars into soluble forms and least utilization of organic acids. The results of present investigations are in conformity with the finding of Aoyagi et al., (1997) in onion. 
Table.1 Effect of field application of salicylic acid, azoxystrobin and cycocel on sprouting (\%) of onion cv. Arka Kalyan

\begin{tabular}{|c|c|c|c|c|c|}
\hline \multirow{3}{*}{ Treatments } & \multicolumn{4}{|c|}{ Sprouting (\%) } & \multirow[t]{3}{*}{ Mean } \\
\hline & \multicolumn{4}{|c|}{ Storage (Days) } & \\
\hline & 30 & 60 & 90 & 120 & \\
\hline $\mathrm{T}_{1}$ & $3.94^{\mathrm{a}}$ & $5.92^{\mathrm{a}}$ & $9.43^{\mathrm{a}}$ & $10.93^{\mathrm{a}}$ & 7.56 \\
\hline $\mathbf{T}_{2}$ & $2.62^{d}$ & $3.78^{\mathrm{bc}}$ & $5.11^{\mathrm{d}}$ & $7.10^{c}$ & 4.65 \\
\hline $\mathbf{T}_{3}$ & $2.38^{\mathrm{d}}$ & $3.48^{\mathrm{cd}}$ & $4.62^{\mathrm{e}}$ & $7.07^{\mathrm{c}}$ & 4.39 \\
\hline $\mathbf{T}_{4}$ & $1.91^{\mathrm{e}}$ & $3.08^{\text {cde }}$ & $4.47^{\mathrm{ef}}$ & $5.84^{\mathrm{d}}$ & 3.83 \\
\hline$T_{5}$ & $1.68^{\mathrm{ef}}$ & $2.91^{\text {cde }}$ & $4.23^{\mathrm{fg}}$ & $5.37^{d}$ & 3.55 \\
\hline $\mathbf{T}_{6}$ & $1.72^{\mathrm{ef}}$ & $2.72^{\mathrm{def}}$ & $4.00^{\mathrm{gh}}$ & $5.70^{\mathrm{d}}$ & 3.65 \\
\hline $\mathbf{T}_{7}$ & $3.48^{\mathrm{b}}$ & $5.99^{\mathrm{a}}$ & $7.63^{b}$ & $9.12^{b}$ & 6.56 \\
\hline $\mathbf{T}_{8}$ & $3.39^{\mathrm{bc}}$ & $4.50^{\mathrm{b}}$ & $7.33^{c}$ & $8.32^{b}$ & 5.89 \\
\hline$T_{9}$ & $1.82^{\mathrm{e}}$ & $2.90^{\text {cde }}$ & $3.84^{\mathrm{h}}$ & $5.30^{\mathrm{d}}$ & 3.47 \\
\hline $\mathbf{T}_{10}$ & $3.03^{c}$ & $4.47^{\mathrm{b}}$ & $5.22^{\mathrm{d}}$ & $6.91^{\mathrm{c}}$ & 4.91 \\
\hline$T_{11}$ & $1.42^{\mathrm{fg}}$ & $2.47^{\mathrm{ef}}$ & $3.07^{i}$ & $4.32^{\mathrm{e}}$ & 2.82 \\
\hline$T_{12}$ & $1.16^{\mathrm{g}}$ & $1.93^{\mathrm{f}}$ & $2.63^{j}$ & $3.30^{\mathrm{f}}$ & 2.26 \\
\hline Mean & 2.38 & 3.68 & 5.13 & 6.61 & 4.45 \\
\hline S. Em \pm & 0.13 & 0.31 & 0.09 & 0.30 & 0.21 \\
\hline CD@5\% & 0.39 & 0.92 & 0.28 & 0.91 & 0.63 \\
\hline
\end{tabular}

Note: Values with the same superscripts in same column are not significantly different by Duncan Multiple Range Test at $\mathrm{p} \leq 0.05$

Table.2 Effect of field application of salicylic acid, azoxystrobin and cycocel on total soluble solids (TSSoB) of onion bulbs (cv. Arka Kalyan) stored under ambient condition

\begin{tabular}{|c|c|c|c|c|c|c|}
\hline \multirow{3}{*}{ Treatments } & \multicolumn{5}{|c|}{ TSS $\left({ }^{\circ} \mathbf{B}\right)$} & \multirow{3}{*}{ Mean } \\
\hline & \multicolumn{5}{|c|}{ Storage (Days) } & \\
\hline & Initial & 30 & 60 & 90 & 120 & \\
\hline $\mathbf{T}_{1}$ & 13.07 & $13.63^{\mathrm{e}}$ & $14.17^{\mathrm{ef}}$ & $14.86^{\mathrm{ef}}$ & $14.31^{\mathrm{d}}$ & 14.23 \\
\hline $\mathbf{T}_{2}$ & 13.47 & $13.76^{\mathrm{e}}$ & $14.06^{\mathrm{f}}$ & $14.60^{f}$ & $14.30^{\mathrm{d}}$ & 14.22 \\
\hline $\mathbf{T}_{3}$ & 13.37 & $13.82^{\mathrm{de}}$ & $14.30^{\text {def }}$ & $14.83^{\text {ef }}$ & $14.37^{\text {cd }}$ & 14.26 \\
\hline $\mathbf{T}_{4}$ & 13.70 & $14.23^{\mathrm{bcd}}$ & $15.00^{\mathrm{ab}}$ & $15.53^{\mathrm{ab}}$ & $14.70^{\mathrm{ab}}$ & 14.88 \\
\hline $\mathbf{T}_{5}$ & 13.80 & $14.30^{\mathrm{abc}}$ & $14.73^{\text {bcd }}$ & $15.18^{\text {bcde }}$ & $14.62^{\mathrm{abc}}$ & 14.75 \\
\hline $\mathbf{T}_{6}$ & 13.10 & $13.80^{\mathrm{de}}$ & $14.52^{\text {cdef }}$ & $15.07^{\text {cde }}$ & $14.58^{\mathrm{bcd}}$ & 14.43 \\
\hline $\mathbf{T}_{7}$ & 13.43 & $14.20^{\text {bcd }}$ & $14.83^{\mathrm{abc}}$ & $15.56^{\mathrm{ab}}$ & $14.64^{\mathrm{abc}}$ & 14.83 \\
\hline $\mathbf{T}_{8}$ & 13.63 & $13.90^{\text {cde }}$ & $14.53^{\text {cde }}$ & $15.03^{\text {def }}$ & $14.53^{\text {bcd }}$ & 14.54 \\
\hline $\mathbf{T}_{9}$ & 13.50 & $13.80^{\text {de }}$ & $13.33^{\mathrm{g}}$ & $14.08^{\mathrm{g}}$ & $13.93^{\mathrm{e}}$ & 13.93 \\
\hline $\mathbf{T}_{10}$ & 13.73 & $14.47^{\mathrm{ab}}$ & $14.89^{\mathrm{abc}}$ & $15.49^{\mathrm{abc}}$ & $14.69^{\mathrm{ab}}$ & 14.91 \\
\hline$T_{11}$ & 13.67 & $14.73^{\mathrm{a}}$ & $15.24^{\mathrm{a}}$ & $15.76^{\mathrm{a}}$ & $14.89^{\mathrm{a}}$ & 15.14 \\
\hline $\mathbf{T}_{12}$ & 13.70 & $14.43^{\mathrm{ab}}$ & $14.82^{\mathrm{abc}}$ & $15.45^{\mathrm{abcd}}$ & $14.74^{\mathrm{ab}}$ & 14.93 \\
\hline Mean & 13.51 & 14.09 & 14.54 & 15.12 & 14.52 & 14.37 \\
\hline S. Em \pm & 0.15 & 0.14 & 0.15 & 0.15 & 0.09 & 0.14 \\
\hline CD@5\% & NS & 0.44 & 0.47 & 0.45 & 0.30 & 0.41 \\
\hline
\end{tabular}

Note: Values with the same superscripts in same column are not significantly different by Duncan Multiple Range Test at $\mathrm{p} \leq 0.05$. 
Table.3 Effect of on field application of salicylic acid, azoxystrobin and cycocel on total pyruvic acid ( $\mu$ moles/g) of onion bulbs (cv. Arka Kalyan) stored under ambient condition

\begin{tabular}{|c|c|c|c|c|c|c|}
\hline \multirow{3}{*}{ Treatments } & \multicolumn{5}{|c|}{ Pyruvic acid ( $\mu$ moles/g) } & \multirow{3}{*}{ Mean } \\
\hline & \multicolumn{5}{|c|}{ Storage (Days) } & \\
\hline & Initial & 30 & 60 & 90 & 120 & \\
\hline $\mathbf{T}_{1}$ & $5.27^{j}$ & $5.10^{\mathrm{e}}$ & $4.77^{\mathrm{e}}$ & $4.07^{\mathrm{g}}$ & $3.43^{\mathrm{e}}$ & 4.53 \\
\hline $\mathbf{T}_{2}$ & $9.03^{d}$ & $8.47^{b}$ & $7.97^{b}$ & $7.40^{c}$ & $6.60^{b}$ & 7.81 \\
\hline $\mathbf{T}_{3}$ & $9.13^{\mathrm{cd}}$ & $9.20^{\mathrm{a}}$ & $8.80^{\mathrm{a}}$ & $8.23^{\mathrm{a}}$ & $6.63^{b}$ & 7.96 \\
\hline $\mathbf{T}_{4}$ & $7.40^{\mathrm{h}}$ & $6.83^{d}$ & $6.37^{\mathrm{d}}$ & $5.97^{\mathrm{e}}$ & $5.30^{\mathrm{d}}$ & 6.37 \\
\hline$T_{5}$ & $9.30^{\mathrm{bc}}$ & $9.13^{\mathrm{a}}$ & $8.67^{\mathrm{a}}$ & $8.10^{\mathrm{a}}$ & $7.67^{\mathrm{a}}$ & 8.57 \\
\hline$T_{6}$ & $9.50^{\mathrm{a}}$ & $9.23^{\mathrm{a}}$ & $8.80^{\mathrm{a}}$ & $8.23^{\mathrm{a}}$ & $7.90^{\mathrm{a}}$ & 8.71 \\
\hline $\mathbf{T}_{7}$ & $7.63^{g}$ & $6.90^{d}$ & $6.33^{d}$ & $5.63^{d}$ & $5.17^{\mathrm{d}}$ & 6.33 \\
\hline $\mathbf{T}_{8}$ & $8.50^{f}$ & $8.03^{c}$ & $7.43^{\mathrm{c}}$ & $6.97^{\mathrm{d}}$ & $6.17^{\mathrm{c}}$ & 7.42 \\
\hline $\mathbf{T}_{9}$ & $8.73^{\mathrm{e}}$ & $8.07^{\mathrm{c}}$ & $7.70^{\mathrm{bc}}$ & $7.07^{\mathrm{d}}$ & $6.60^{b}$ & 7.63 \\
\hline$T_{10}$ & $7.20^{\mathrm{i}}$ & $6.87^{\mathrm{d}}$ & $6.47^{\mathrm{d}}$ & $5.90^{\text {ef }}$ & $5.27^{\mathrm{d}}$ & 6.34 \\
\hline $\mathrm{T}_{11}$ & $9.00^{d}$ & $8.67^{b}$ & $7.90^{b}$ & $7.10^{\mathrm{cd}}$ & $6.60^{b}$ & 7.81 \\
\hline $\mathbf{T}_{12}$ & $9.33^{\mathrm{ab}}$ & $9.00^{\mathrm{a}}$ & $8.57^{\mathrm{a}}$ & $7.73^{b}$ & $6.73^{b}$ & 8.31 \\
\hline Mean & 8.34 & 7.96 & 7.39 & 6.75 & 6.14 & 7.30 \\
\hline S. Em \pm & 0.06 & 0.07 & 0.10 & 0.10 & 0.09 & 0.08 \\
\hline CD@5\% & 0.20 & 0.25 & 0.31 & 0.31 & 0.26 & 0.27 \\
\hline
\end{tabular}

Note: Values with the same superscripts in same column are not significantly different by Duncan Multiple Range Test at $\mathrm{p} \leq 0.05$.

\section{Pyruvic acid content}

Pungency level and total soluble sugars are important quality attributes of onion bulbs for export. During prolonged storage of 4 months the pyruvic acid content showed decreasing trend which was presented in the Table 3 . The pyruvic acid content is found to be maximum in treatment $\mathrm{T}_{6}$ (seedling dip in salicylic acid @ $2 \mathrm{mM}+$ pre-harvest spray of salicylic acid @ $2 \mathrm{mM}$ and azoxystrobin @ $0.1 \%$ at $60+90$ DAT) $\left(8.71 \mu\right.$ moles/g) followed by $\mathrm{T}_{5}$ (preharvest spray of salicylic acid @ $2 \mathrm{mM}$ and azoxystrobin @ $0.1 \%$ at $60+90$ DAT followed by CCC 2500 ppm foliar spray 90 DAT) $(8.57 \mu$ moles $/ g)$. Combined application of the chemicals resulted in quantitative increase in pyruvic acid content which may be due to the fungicide azoxystrobin is well known to influence several physiological processes likely through interaction with electron transfer in plant mitochondria (Bartlett et al., 2002) 6. Application of SA is known to improve the enzyme activity and translocation of metabolites (Amin et al., 2007). SA is an endogenous growth regulator with phenolic nature, which participates in regulation of several physiological processes in plants (Khan et al., 2003).

In conclusion, the present experiment revealed that the combined application of salicylic acid, azoxystrobin and cycocel in field condition improve the storability along with retaining the quality of onion bulbs by reducing sprouting and increasing pyruvic acid content, total soluble solids in onion $\mathrm{cv}$. Arka kalyan.

Abbreviations: DAT- Days after transplanting, SA- Salicylic acid, CCCcycocel. 


\section{References}

Amin, A. A., Rashad, E. M. and EL-Abagy, H. M. H., 2007. Physiological effect of indole - 3 - butyric acid and salicylic acid on growth, yield and chemical constituents of onion plants. J Appl Sci Res. 3(11): 1554-1563.

Anbukkarasi, V., Paramaguru, P., Pugalendhi, L., Ragupathi, N and Jeyakumar, P., 2013. Studies on pre and post-harvest treatments for extending shelf life in onion- a review. Agri. Reviews. 34(4): 256- 268.

Anonymous, 2016. National horticulture database. min. of Agrico. Government of India.

Antonio, D., María Victoria, C., Miquel, R., Jaume, F., Sebastian, M., and José, F., 2012. The effect of strobilurins on leaf gas exchange, water use efficiency and $\mathrm{ABA}$ content in grapevine under field conditions. J. Plant Physiol. 169(1): 379- 386.

Aoyagi, M., Makino, H. and Sato, J., 1997. The effect of storage temperature on keeping quality of onion bulbs. Res. B. Aichiken, 9: 54-60.

Bartlett, D. W., Clough, J. M., Godwin, J. R., Hall, A. A., Hamer, M. and ParrDobrzanski，B. 2002. Review: the strobilurin fungicides. Pest Manag Sci. 58(1): 649-62.

Chope, G. A., Terry, L. and White, P., 2006. Effect of controlled atmosphere climates. In: H. D. rabinowitch and J. L. Brewster (eds), pp. 31-48.

Ketter, C. A. and Randle, W. M., 1998. Pungency assessment in onions. Proceeding of the $19^{\text {th }}$ Workshop and Conference of the Association for Biology Laboratory Education (ABLE). 177-196.

Khan, W., Prithiviraj, B. and Smith, D. L., 2003. Photosynthetic response of corn and soybean to foliar application of salicylates. J Plant Physiol. 160: 485182.

Kukanoor, L., 2005. Post-harvest studies in onion Cv. N-53. Ph.D. (Hort.) Thesis, Univ. Agric. Sci., Dharwad.

Sakhabutdinova, A. R., Fatkhutdinova, D. R., Bezrukova, M. V., and Shakirova, F. M., 2003. Salicylic acid prevents the damaging action of stress factors on wheat plants. Bulg. J. Plant Physiol., 314-319.

Shivakumar and Chandrashekar S. Y., 2014. Physio-chemical changes during post harvest handling of onion (Allium cepa L.)-a review. Agric. Rev., 35(3): 225-232.

\section{How to cite this article:}

Ayeeshya Hasansab Kolhar, S.L. Jagadeesh and Vijaymahantesh. 2019. Effect of Seedling Dip and Pre Harvest Foliar Application of Growth Regulators and Fungicide on Sprouting and Chemical Parameters in Onion (Allium cepa L.) var. Arka Kalyan. Int.J.Curr.Microbiol.App.Sci. 8(04): 970-975. doi: https://doi.org/10.20546/ijcmas.2019.804.112 